\title{
Introduction: the first 100 years
}

\section{BO DRASAR}

London School of Hygiene and Tropical Medicine, London, UK

(Bo.Drasar@1shtm.ac.uk)

The journal that is now Epidemiology \& Infection was founded in 1901 as the Journal of Hygiene 'to fulfil a definite purpose by serving as a focus to Englishspeaking investigators for works in physics, chemistry, physiology, pathology, bacteriology, parasitology and epidemiology in relation to hygiene and preventive medicine'. In 1987 the name of the journal was changed to Epidemiology \& Infection. The reasons for this change were articulated by John Pattison [1] on one of the few occasions that the Editor has directly addressed the readership and formalized the historic shift towards microbiology and epidemiology.

The fiftieth anniversary of the journal was celebrated by an account of the founding of the journal and a tribute to Editors and others associated with the publication [2]. The centenary should not pass without mention of those many people who have shepherded the journal through the past 100 years. The Editors are listed in Appendix 1 and other contributors in Appendix 2. The people listed in Appendix 2 include some who became Editors and some who, in another era of the journal's existence, would have been Editors and members of the Editorial Board.

In celebration of this centenary a small number of papers are republished here. The choice has been problematic and those familiar with the historic issues of the journal may search in vain for their favourites. In a limited compass it has not been possible to illustrate all aspects of the journal. Although we now think of the journal as a medium for the communication of original research in microbiology and epidemiology, in the past the scope was much wider and included official reports on a variety of topics and research over the whole area of hygiene as originally defined.
The intention is to republish papers of lasting importance and historical significance. The choice has been limited to papers related to microbiology and epidemiology. This decision has excluded many papers of historic importance and important examples might include studies on compressed-air sickness, fundamental to the health of deep-sea divers [3]; on silicosis, fundamental to the health of miners [4]; and nutrition $[5,6]$. The final decisions were informed, when appropriate, by citation analysis and by historical appreciation of the subject. Those papers included are grouped together to illustrate major subject areas that have provided continued themes in the journal.

\section{Emerging infectious diseases}

The movement of people into new environments brings about changes in the ecological balances of which we are a part, thus new diseases emerge and are recognized. This has happened for as long as history has been recorded and continues to this day. The process is well illustrated by the papers chosen here. The investigation of yellow fever by Reed [7] shows how entry of a susceptible population into the wrong environment can cause an epidemic (yellow fever was the first human disease shown to be caused by a virus). The investigation of melioidosis by Whitmore [8] illustrates how systematic study can lead to the description of a 'new' disease that was previously unrecognized. Similar lessons can be learned from consideration of the investigation of pig-bel [9].

\section{Microbiological methods}

The advance of scientific knowledge is dependent on the development and dissemination of new technical 
methods. This is an area in which the journal has excelled and many of the methods first described here are still in use or form the basis of current methods. Many have become part of the routine furniture of microbiology. The use of bile salts in bacteriological media as pioneered by MacConkey in 1908 [10] has long been routine practice in the clinical and public health laboratory. From the same volume we have chosen to reproduce Chick and Martin [11] on the standardization of disinfectant solutions. This study forms the basis of all later advances in this area.

Complement-fixation tests are important in both routine diagnostic laboratories and research laboratories so the pioneering studies of Mackie and Finkelstein are reproduced as well [12].

The counting and detection of bacteria are important aspects of bacteriology. One of the most complete appreciations of the counting of viable bacteria was published in the journal in 1938 by Miles and Misra [13] and the method they described is still used today. Of equal practical importance was the test for faecal contamination of drinking water described by Clegg and Sherwood [14], a paper which forms the basis of much public health microbiology.

It is not possible to mention or to reproduce all the methodological advances that have been published in the journal - suffice it to say that they have been many and include pioneering work on freeze-drying [15] and phage-typing of Staphylococcus aureus [16].

The study by Williams and Rippon [16] still forms the basis for the surveillance of that modern plague in hospital infection-MRSA. But to understand some of the problems of hospital infection in the preantibiotic era, the paper by Wright [17] provides some perspective on modern problems. Similarly, if modern commentators were more aware of the work by Lidwell and Lowbury [18-22] on the role of dust in hospital infection, some of the discussions on the cleaning of hospitals would have a more rational basis.

\section{Immunity}

Among the many firsts represented among the publications reviewed mention must be made of the first demonstration of the secondary response by the immune system to a second dose of antigen. This paper by Glenny and Südmerson [23] represents a fundamental advance in our understanding of immunity.
The theme of immunity to viruses was taken further by the study by Kingsbury [24], in that this was the beginning of the measles vaccine that has been so successful in preventing this disease.

The study of immunity cannot be complete without mention of smallpox. It is notable that the vaccine used in the successful eradication programme was described by Collier in a paper published in this journal [25].

\section{Molecular biology}

Alhough the journal is notable for many firsts, the one that has attracted most attention is the paper by Fred Griffith on the transformation of pneumococci. This publication [26] is regarded as the foundation text of molecular biology. Readers will also be interested in the appreciation by Hayes published in 1966 [27]. Important though the work of Griffith is it must not overshadow other work published in the journal. That interest in bacterial genetics pre-dates the establishment of a central role for DNA is well illustrated by the seminal work of Stocker [28]. The discovery of plasmids was documented in English by Datta [29].

\section{Epidemiology}

The change of name of the journal in 1987 highlighted one of the major themes among our publications. Epidemiology, in this context - the understanding of and control of spread of infections in populations -, has been important for many years but has become more significant as control has become achievable. Recently there has been much talk in the popular press of the concept of 'herd immunity'. Few will realize that they are quoting Topley and Wilson who coined the term, another first for the journal! [30].

Epidemiology, as represented in the journal, can be divided roughly into two categories: these are the investigation of populations and the theoretical treatment of the spread of infections. In that theories must explain the data, and the type of data collected is informed by theory, the distinction is not absolute.

Among the most highly cited papers published in the renamed journal was the account of the Stonehouse survey of meningococci [31], which sought to explain the microbiological context of outbreaks of meningitis. The extension of mathematical modelling has been a feature of recent attempts to predict outcomes of interventions [32] and explain the 
long-term dynamics of disease [33]. These papers reflect the increase in the sophistication of analysis made possible by advances in mathematical techniques and the power of computing.

\section{The future}

Undoubtedly the journal will continue to be a major resource for all those studying infection. New challenges await; some like new-variant CJD may be with us for a long time. How long is a matter of speculation but a recent paper [34] may provide a clue, indeed the results of cadaveric dura mater transplantation may enable us to understand incubation periods and thus calculate risk for prion-related disease. The existence of such data and the need to make it widely available provides the ultimate justification for the journal and will secure its future.

\section{Update: since the centenary, May 2003}

The world has changed since 2001. Bioterrorism has come to the forefront of our concerns, whilst new diseases such as SARS have burst on an unsuspecting but not entirely unprepared world. The classic papers published in the journal show us how these threats can be combated. The principles involved are not new indeed, advances in molecular biology show that some problems have been with us a long time $[35,36]$.

The journal continues to publish on these established problems [37]. We have continued to highlight the epidemiological approaches to dealing with infectious diseases: our emphases on modelling and on both veterinary and human infections bear this out [38]. From this brief selection it can be seen that the expectations for our second century will be fulfilled.

\section{References}

1. Pattison JR. Epidemiology and Infection - Hygiene by another name. Epidemiol Infect 1987; 98: 1-2.

2. Graham-Smith GS. An account of the Journal of Hygiene, 1901-1950. J Hyg 1951; 49: 1-12.

3. Boycott AE, Damant CCC, Haldane JS. The prevention of compressed-air sickness. J Hyg 1908; 8: 342-443.

4. Jones WR. Silicotic lungs: the materials they contain. J Hyg 1933 33: 307-329.

5. Ferguson M. The diets of labouring class families during the course of the war. J Hyg 1919-1920.18: 409-416.

6. Widdowson EM, McCance RA. Iron in human nutrition. J Hyg 1936; 36: 13-23.
7. Reed W. Recent researches concerning the etiology, propagation, and prevention of yellow fever, by the United States Army Commission. J Hyg 1902; 2: 101-119.

8. Whitmore A. An account of a glanders-like disease occurring in Rangoon. J. Hyg 1913; 13: 1-34.

9. Murrell TGC, Egerton JR, Rampling A, Samels J, Walker PD. The ecology and epidemiology of pig-bel syndrome in man in New Guinea. J Hyg 1966; 64: 375-396.

10. MacConkey AT. Bile salt media and their advantages in bacteriological examinations. J Hyg 1908; 8: 322-334.

11. Chick H, Martin C. The principles involved in the standardization of disinfectants and the influence of organic matter upon germicidal value. J Hyg 1908; 8: 654-697.

12. Mackie TJ, Finkelstein MH. Complement-fixation by the interaction of normal serum and bacterial suspensions of normal serum and bacterial suspensions $-\mathrm{a}$ contribution to the study of natural immunity phenomenon. J Hyg 1930; 30: 1-24.

13. Miles AA, Misra JO. The estimation of bactericidal power of the blood. J Hyg 1938; 38: 732-749.

14. Clegg LFL, Sherwood HP. Incubation at $44{ }^{\circ} \mathrm{C}$ as a test for faecal coli. J Hyg 1939; 39: 361-374.

15. Fry RM, Greaves RIN. The survival of bacteria during and after drying. J Hyg 1951; 49: 220-246.

16. Williams REO, Rippon JE. Bacteriophage typing of Staphylococcus aureus. J Hyg 1952; 50: 320-353.

17. Wright J. Nosocomial infections in children's wards. J Hyg 1940; 40: 647-672.

18. Lowbury EJ. The persistence of dust in occupied rooms. J Hyg 1950; 48: 1-5.

19. Lidwell OM, Lowbury EJ. The survival of bacteria in dust. I. The distribution of bacteria in floor dust. J Hyg 1950; 48: 6-20.

20. Lidwell OM, Lowbury EJ. The survival of bacteria in dust. II. The effect of atmospheric humidity on the survival of bacteria in dust. J Hyg 1950; 48: 21-27.

21. Lidwell OM, Lowbury EJ. The survival of bacteria in dust. III. The effect of light on the survival of bacteria in dust. J Hyg $1950 ;$ 48: 28-38.

22. Lidwell OM, Lowbury EJ. The survival of bacteria in dust. IV. The effect of atmospheric humidity and the bactericidal action of ultra-violet light. J Hyg 1950; 48 : 39-43.

23. Glenny AT, Südmerson HJ. Notes on the production of immunity to diphtheria toxin. J Hyg 1921; 20: 176-220.

24. Kingsbury AN. The serum prophylaxis of measles. J Hyg 1927; $27: 1-13$.

25. Collier L. The development of a stable smallpox vaccine. J Hyg 1955; 53: 76-101.

26. Griffith F. The significance of pneumococcal types. J Hyg 1928; 27 : 113-159.

27. Hayes W. The discovery of pneumococcal type transformation: an appreciation. J Hyg 1966; 64: 177-184

28. Stocker BAD. Measurements of rate of mutation of flagellar antigenic phase in Salmonella typhimurium. J Hyg 1949; 47: 398-413. 
29. Datta N. Transmissible drug resistance in an epidemic strain of Salmonella typhimurium. J Hyg, 1962; 60: 301-310.

30. Topley WWC, Wilson GS. The spread of bacterial infection, the problem of herd immunity. J Hyg 1923; 21: 237-249.

31. Cartwright KAV, Stuart JM, Jones DM, Noah ND. The Stonehouse survey-nasopharyngeal carriage of meningococci and Neisseria lactamica. Epidemiol Infect 1987; 99: 591-601.

32. McLean AR, Anderson RM. Measles in developing countries. 2. The predicted impact of mass vaccination. Epidemiol Infect 1988; 100: 419-442.

33. Vynnycky E, Fine PEM. The long-term dynamics of tuberculosis and other diseases with long serial intervals: implications of and for changing reproduction numbers. Epidemiol Infect 1998; 121: 309-324.
34. Nakamura $\mathbf{Y}$, Yanagawa $\mathbf{H}$, Kitamoto $T$, Sato $T$. Epidemiological features of 65 Creutzfeldt-Jakob disease patients with a history of cadaveric dura mater transplantation in Japan. Epidemiol Infect 2000; 125: 201-205.

35. Zink AR, Grabner W, Reischl U, Wolf H, Nerlich AG. Molecular study of human tuberculosis in three geographically distinct and time delineated populations in ancient Egypt. Epidemiol Infect 2003; 130: 239-250.

36. Hayward AC, Goss S, Drobniewski F, et al. Molecular epidemiology of tuberculosis in inner London. Epidemiol Infect 2002; 128: 175-184.

37. Heyman P, Klingström J, de Jaegere F, et al. Tula hantavirus in Belgium. Epidemiol Infect 2002; 128: 251-256.

38. Dickinson JA, Wun YT, Wong SL. Modelling death rates for carriers of hepatitis B. Epidemiol Infect 2002; 128: $83-92$. 